Süleyman Demirel Üniversitesi Fen Edebiyat Fakültesi Fen Dergisi

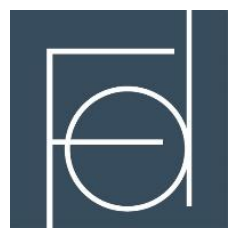

Süleyman Demirel University Faculty of Arts and Sciences Journal of Science

2019, 14: 112-126

DOI: $10.29233 /$ sdufeffd.457567

Atıf/Citation: A. SAVCI, Y. ALAN, E. F. KOÇPINAR, M. KURŞAT, S. TOPDEMİR, M. KARATAŞ, B. ÇAKMAK, "Tanacetum kotschyi (Boiss.) Grierson ve Tanacetum tomentellum (Boiss.) Grierson Ekstraktlarının Fenolik Madde İçeriği ve Biyolojik Aktiviteleri”, Süleyman Demirel Üniversitesi Fen Edebiyat Fakültesi Fen Dergisi, 14, 112-126, 2019.

\title{
Tanacetum kotschyi (Boiss.) Grierson ve Tanacetum tomentellum (Boiss.) Grierson Ekstraktlarının Fenolik Madde İçeriği ve Biyolojik Aktiviteleri
}

\author{
Ahmet SAVCI ${ }^{* 1}$, Yusuf ALAN², Enver Fehim KOÇPINAR ${ }^{3}$, Murat KURŞAT ${ }^{4}$, Siraç \\ TOPDEMIR $^{5}$, Mizbah KARATAŞ ${ }^{5}$, Birsen ÇAKMAK ${ }^{6}$ \\ ${ }^{1}$ Muş Alparslan Üniversitesi, Fen-Edebiyat Fakültesi, Moleküler Biyoloji ve Genetik Bölümü, \\ 49250, Muş, Türkiye \\ ${ }^{2}$ Muş Alparslan Üniversitesi, Eğitim Fakültesi, Temel Eğitim Bölümü, 49250, Muş, Türkiye \\ ${ }^{3}$ Muş Alparslan Üniversitesi, Sağglk MYO, Tibbi Hizmetler ve Teknikler Bölümü, 49250, Muş, \\ Türkiye \\ ${ }^{4}$ Bitlis Eren Üniversitesi, Fen-Edebiyat Fakültesi, Biyoloji Bölümü, 13000, Bitlis, Türkiye \\ ${ }^{5}$ Bitlis Eren Üniversitesi, Fen Bilimleri Enstitüsü̈, 13000, Bitlis, Türkiye \\ ${ }^{6}$ Muş Alparslan Üniversitesi, Fen Bilimleri Enstitüsü, 49250, Muş Türkiye \\ *yazlşllan yazar e-posta: a.savci@alparslan.edu.tr
}

(Alınış / Received: 05.09.2018, Kabul / Accepted: 18.04.2019, Yaylmlanma / Published: 31.05.2019)

Özet: Bitkiler, iyileştirici etkilerinden dolayı, eski zamanlardan beri tedavi amaçlı olarak kullanılmaktadır. Bu çalışmada Bitlis ve Van illerinden toplanan Tanacetum kotschyi (Boiss.) Grierson (ateş pireotu) ve Tanacetum tomentellum (Boiss.) Grierson (yıldızlı pireotu)'dan elde edilen etanol ekstraktlarının 14 farklı fenolik içeriği HPLC ile belirlenmiştir. Fenoliklerin geneli antioksidan olarak bilindiğinden dolayı bitkilerin antioksidan özellikleri de bilimsel pek çok çalışmada önemli sayılmıştır. Bu nedenle soxhlet ekstraksiyon metodu ile bu bitkilerden etanol ekstraktları hazırlanmış ve in vitro şartlarda biyolojik aktiviteleri araştırılmıştır. Bu amaçla ilk olarak bu ekstraktların total antioksidan aktiviteleri, DPPH ve ABTS radikal giderme aktiviteleri, FRAP ve CUPRAC indirgenme metodları ile demir ve bakır indirgeme kuvvetleri ölçülerek antioksidan güçleri, antioksidan oldukları kanıtlanmış çeşitli standartlar (Bütillenmiş hidroksianisol: BHA, Bütillenmiş hidroksitoluen: BHT ve $\alpha$-tokoferol: $\alpha$-toc) ile karşılaştırılmıştır. Toplumda bitkiler, mikroorganizma kaynaklı pek çok cilt hastalığ 1 başta olmak üzere, günümüzün en önemli hastalıklardan olan kanser gibi DNA hasarına bağlı bazı hastalıklarda da alternatif bir tedavi yöntemi olarak kullanıldığı ve bu yönüyle bitkilerin pek çok farmakolojik araştırmanın ilgi odağı olduğu yadsınamaz bir gerçektir. Bu nedenle bu çalışmada ekstraktlar, farklı türlerden müteşekkil olan 10 adet mikroorganizma üzerinde denenerek antimikrobiyal aktiviteleri, Pbr322 plazmid DNA's1 üzerinde denenerek DNA koruyucu aktiviteleri araştıılmıştır. Fenolik sonuçlarına göre T. kotschyi ve T. tomentellum ekstraktlarında gallik asit, T. kotschyi ekstraktında ise salisilik asit varlı̆̆ tespit edilememiştir. Buna ek olarak bazı antioksidan aktivite sonuçlarında her iki bitkiden elde edilen etanol ekstraktlarının standartlara benzer aktiviteye sahip olduğu belirlenmiştir. Oyuk agar metodunun kullanıldığ antimikrobiyal aktivite sonuçlarına göre; T. tomentellum ekstraktının Staphylococcus aureus üzerinde, T. kotschyi ekstraktının ise Candida albicans ve Klebsiella pneumonia üzerinde en iyi aktiviteyi sergilediği tespit edilmiştir. Ayrıca T. Kotschyi ekstraktı Saccharomyces cereviciae üzerinde herhangi bir aktivite göstermezken, genel olarak ekstraktların bütün test mikroorganizmaları üzerinde antimikrobiyal etkiye sahip olduğu gözlenmiştir. Son olarak 
ekstraktların DNA üzerindeki koruyucu etkisi araştırılmıştır. T. kotschyi ekstraktının, plazmid DNA üzerinde koruyucu bir etkisinin olmadığı, $T$. tomentellum ekstraktının ise $\mathrm{H}_{2} \mathrm{O}_{2}+$ DMSO'un DNA üzerindeki süpürücü etkisini ortadan kaldırarak kararlı hale gelmesinde etkili olduğu tespit edilmiştir. Bu çalışmadan elde edilen veriler, ekstraktların genel olarak güçlü biyolojik aktivitelere sahip olduğunu göstermektedir.

Anahtar kelimeler: Tanacetum kotschyi, Tanacetum tomentellum, Fenolik, Antimikrobiyal, Antioksidan

\title{
Phenolic contents and biological activities of Tanacetum kotschyi (Boiss.) Grierson and Tanacetum tomentellum (Boiss.) Grierson extracts
}

\begin{abstract}
Plants have been used for therapeutic purposes since ancient times because of their healing effects. In present study, T. kotschyi (Boiss.) Grierson and Tanacetum tomentellum (Boiss.) Grierson plants were collected from Van and Bitlis province and the extracts were prepared from them. Then, 14 different phenolic contents were determined. Since the phenolics are known as antioxidants, the importance of antioxidants properties of the plants is emphasized in many studies. For this purpose, the extracts were prepared from these plants and in vitro biological activities were investigated. Firstly, total antioxidant activities, DPPH and ABTS radical scavenging activities and iron and cupric reduction activities were measured using the extracts and the results were compared with the standard antioxidants (Butylated hidroxyanisole: BHA, Butylated hidroxitoluen: BHT and $\alpha$-tocopherol: $\alpha$-toc). Today, the plants are used as an alternative treatment in many skin disease caused by microorganism and in the treatment of several diseases such as cancer. In this aspect, it is an undeniable fact that plants are at the focal point of many research. For this purpose, the antimicrobial activities of the extracts on 10 different microorganisms and the DNA protective properties on pBR322 plasmid DNA were determined. According to the phenolic results, In addition to the absence of gallic acid in T. kotschyi and T. tomentellum extracts, salycilic acid could not be detected in $T$. Kotschyi extract. In vitro antioxidant activities were determined by using total antioxidant activity, DPPH and ABTS radical scavenging activities, FRAP and CUPRAC reduction methods and the results were compared with BHA, BHT and $\alpha$-tocopherol standard antioxidant results. The ethanol extracts obtained from both plants were found to have close activity to the standards. According to antimicrobial activity results of hollow agar method, T. tomentellum extracts and T. kotschyi were found to have the highest activity on Staphylococcus aureus, and Candida albicans and Klebsiella pneumonia respectively. It was observed that the extracts have antimicrobial effect on all test microorganisms. on the contrary, only T. kotschyi extract had no antifungal effect on Saccharomyces cereviciae. Finally, the protective effects of extracts on DNA were investigated. T. kotschyi extract had no protective effect on plasmid DNA however; T. tomentellum extract was able to stabilize the DNA by eliminating the scavenging effect of $\mathrm{H}_{2} \mathrm{O}_{2}+$ DMSO. Data from this study show that extracts generally have strong biological activities.
\end{abstract}

Keywords: Tanacetum kotschyi, Tanacetum tomentellum, Phenolic, Antimicrobial, Antioxidant

\section{Giriş}

Sentetik ilaçların yan etkilerinden dolayı, tedavi edici ve şifa kaynağı olarak bitkilerin kullanımlarına olan ilgi gün geçtikçe artmaktadır [1,2]. Günümüzde de bitkiler farmakolojik sahada ilaç hammaddesi olarak kullanılmaktadır [3].

Geniş bir habitata sahip olan Asteraceae familyasının 23000 türe sahip olduğu bildirilmektedir [4-6]. Türkiye Florasında Asteraceae'e ait toplam 1209 tür kaydedilmiş olup, tür sayısı bakımından familyalar arasında ilk sırada yer almaktadır. Bu türlerin 447'si endemiktir ve endemizm oran1 \%37'dir [7-10]. Avrupa, Asya, Kuzey Afrika ve Kuzey Amerika'da yayılış gösteren Tanacetum, dünyada yaklaşık 160 türle temsil edilir. [11,12]. 
T. kotschyi (ateş pireotu), 8-40 cm boyunda, çok yıllık otsu bir bitkidir. Kireçli kayalar, kaya yarıkları, taş yığınlarında 1450-3580 metre yüksekliklerde doğal olarak yetişir. Doğu Karadeniz, Yukarı Fırat, Yukarı Murat-Van, Hakkâri ve Adana bölümlerinde yayılış gösterirler. T. tomentellum (yıldızlı pireotu), sürünücü ana köke ve çalımsı otsu gövdeye sahip, $25-50 \mathrm{~cm}$ boyunda gri ve gümüşi beyaz renkli, tüylü bir bitkidir. Toprakla örtülü kayalarda, kaya yarıklarında, 1900-2300 metrede doğal olarak yetișen bu bitki, Y. Fırat ve Y. Murat-Van bölümlerinde yayılış gösterirler. [7, 8, 13, 14, 15].

Halk arasında tedavi edici olarak kullanılan Tanacetum türlerinin ayrıca klinik olarak migren tedavisi başta olmak üzere antitümör, antienflamatuvar, antimikrobiyal, antifungal, sitotoksik antiprotozoal, antiülser gibi pek çok rahatsızlığın tedavisinde kullanıldığ pek çok çalışmada vurgulanmıştır [17]. Bitkilerin antimikrobiyal aktivitelerinin yanı sıra antioksidan özellikleri de büyük öneme sahiptir. Hücrenin mitokondriyal metabolizmasının ürünü olarak serbest oksijen radikalleri oluşabilmektedir [18]. Bu radikaller; karbonhidrat, protein, lipit ve DNA molekülü ile reaksiyona girebilir. Bunun sonucunda kalp hastalıkları, sinirsel hastalıklar ve kanserde dâhil olmak üzere çeşitli hastal1klara neden olurlar [18-20].

Daha önceki çalışmalarda $T$. kotschyi ve $T$. tomentellum ile ilgili fenolik madde içeriğinin belirlenmesi ve biyolojik aktivite çalışmalarına rastlanmamıştır. Bu amaçla bu bitkilerin toprak üstü kısımlarından etanol ekstraktı hazırlanarak, bu ekstraktlarda sekonder metabolit olarak bilinen 14 farklı fenolik miktarı HPLC ile belirlenmiştir. Ayrıca bu ekstraktların biyolojik aktivitelerini belirlemek amacıyla, beş farklı yöntem kullanılarak antioksidan özellikleri, üç Gram-pozitif, dört Gram-negatif bakteri ve üç fungusun dâhil olduğu 10 farklı mikroorganizma üzerindeki antimikrobiyal aktiviteleri araştırılmıştır. Son olarak bu ekstraktların, agaroz jel elektroforezi ile pBR322 plazmid DNA'sı üzerindeki koruyucu etkileri incelenmiştir.

\section{Materyal ve Metot}

\subsection{Bitki örneklerinin toplanması ve ekstraksiyonu}

Çalışmada kullanılan T. kotschyi, Van (Artos Dağı) ve T. tomentellum ise Bitlis (Kambos Dağı) ilinde 2014-2015 yılları arasında vejatasyon dönemlerinde toplanmıştır. T. kotschyi (M.KURŞAT-6043) ve T. tomentellum (M.KURŞAT:6044) herbaryum materyali haline getirilerek kodlanmıştır. Örnekler, Bitlis Eren Üniversitesi, Bilim ve Teknoloji Uygulama ve Araştırma Merkezi Laboratuvarı'nda saklanmaktadır.

Bitki örneklerini ekstraksiyona hazırlamak için bitkilerin toprak üstü kısımlarından alınarak gölgede kurutulmaya bırakılmıştır. Ekstraksiyona hazırlanmış olan bitkilerden 50'şer gr alınarak temizlenmiş ve öğütülerek soxhlet yöntemiyle, $300 \mathrm{ml}$ etanol içerisinde ekstrakt elde edilmiştir. Daha sonra evaporatör kullanılarak etanol uzaklaştırılmıştır. Yaklaşık olarak T. kotschyi ve T. tomentellum'dan sırasıyla \% 3,6 ve \% 4,15 verimle ekstrakt elde edilmiştir. Ekstraktlar, HPLC ile fenolik madde miktar tayini ve biyolojik aktivitelerinin in vitro ortamda incelenmesi için koyu renkli cam şişelerde $-18^{\circ} \mathrm{C}$ 'de muhafaza edilmiştir.

\subsection{HPLC ile fenolik madde analizi}

HPLC ile fenolik madde miktarı tayini için 14 farklı standartın (Askorbik asit, Gallik asit, Mirisetin, Absisik asit, Kuersetin, Apigenin, Kaemferol, Kurkumin, Katekol, Vanilin, Kafeik asit, Sinamik asit, Rozmarinik asit ve Salisilik asit) son konsantrasyonları $10 \mathrm{mg} / \mathrm{ml}$ olacak şekilde tartılıp $50 \mathrm{ml}$ 'lik balon jojeler içine 
konulmuştur. Daha sonra \% 1'lik asetik asit ile asetonitril sırasıyla (1/9) oranında karıştırılarak standartlar üzerine eklenmiş ve ardından aynı oranda metanol ilave edilerek standartları çözmek için gerekli olan stok çözelti hazırlanmıştır. Stok çözeltiler seyreltilerek $10 \mathrm{mM}, 25 \mathrm{mM}, 50 \mathrm{mM}, 75 \mathrm{mM}$ ve $100 \mathrm{mM}$ konsantrasyonlarına sahip numuneler oluşturulmuştur [21].

T. kotschyi ve T. tomentellum etanol ekstraktlarının konsantrasyonu $20 \mathrm{mg} / \mathrm{ml}$ olacak şekilde standartta kullanılan stok çözelti kullanılarak seyreltilmiştir. Ekstraktlar, 0,45 $\mu$ 'lik membran filtreden geçirilerek HPLC cihazına yüklenmiştir. HPLC analizinde uygulanan koşullar Tablo 1' de verilmiştir.

Bileşiklerin miktarlarının tespit edilmesinde bileşiklere ait HPLC kromatogramlarından elde edilmiş entegre alanlar ve standart maddelerin ara stok çözeltileri ile hazırlanmış kalibrasyon eğrilerinden yararlanılmıştır.

Tablo 1. HPLC Çalışma Koşulları ve Gradient Elüsyon Programı

\begin{tabular}{|c|c|c|c|c|}
\hline \multicolumn{2}{|c|}{ HPLC çalışma koşulları programı } & \multicolumn{3}{|c|}{ Gradient elüsyon } \\
\hline Model & Agilent Technologies 1260 Infinity II & Süre (dak) & $\mathrm{A}(\%)$ & $\mathrm{B}(\%)$ \\
\hline Kolon & ACE 5 C18 (250x4.6 mm id $)$ & 0 & 90 & 10 \\
\hline Kolon Firin 1 & G7130A & 25 & 60 & 40 \\
\hline Dedektör & 1260 DAD WR & 39 & 40 & 60 \\
\hline Pompa & 1260 Quat Pump VL & 50 & 10 & 90 \\
\hline Mobil Faz & $\begin{array}{l}\text { A: } \% 1 \text { Asetik Asit } \\
\text { B: Asetonitril }\end{array}$ & 55 & 90 & 10 \\
\hline Dedeksiyon & 272,280 ve $310 \mathrm{~nm}$ & & & \\
\hline Otosampler & 1260 Vialsampler & & & \\
\hline Akış Hızı & $1 \mathrm{ml} / \mathrm{dk}$ & & & \\
\hline Kolon Sicakliğ 1 & $28^{\circ} \mathrm{C}$ & & & \\
\hline Enjeksiyon & $20 \mu 1$ & & & \\
\hline
\end{tabular}

\subsection{Biyolojik aktivite çalışmaları}

\subsubsection{Antioksidan Özellikler}

\subsubsection{Total antioksidan aktivite tayini}

Bitki ekstraktlarının lipit peroksidasyonlarını inhibe etme yüzdelerini belirlemek için tiyosiyanat metodu kullanılmıştır [22]. Farklı konsantrasyonlarda stok çözelti, deney tüplerine pipetlenerek hacim tampon çözeltiyle $(\mathrm{pH}: 7,4) 2,5$ ml'ye tamamlanmıştır. Ardından tüplere 2,5 ml linoleik asit emülsiyonu ilave edilmiştir. Ardından $37{ }^{\circ} \mathrm{C}$ 'de inkübasyon yapılmıştır. Her on saatte bir tüplerden 100'er $\mu$ l alınmış, 4,7 ml etanol bulunan deney tüplerine konulmuştur. Üzerine $100 \mu \mathrm{Fe}^{2+}$ ve $100 \mu \mathrm{l} \mathrm{SCN} \mathrm{Sc}^{-}$çzeltisi ilave edilmiştir. $4,8 \mathrm{ml}$ etanol bulunan deney tüpüne $100 \mu \mathrm{Fe}^{2+}$ ve $100 \mu \mathrm{l} \mathrm{SCN}{ }^{-}$ çözeltileri ilave edilerek kör hazırlanmıştır. Kontrol olarak 2,5 ml tampon çözelti ve 2,5 $\mathrm{ml}$ linoleik asit emülsiyonu kullanılmıştır. Spektrofotometrede $500 \mathrm{~nm}$ 'de absorbanslar köre karşı okunmuştur. İnkübasyona, kontrolün maksimum absorbansa ulaşmasıyla son verilmiştir.

\subsubsection{Toplam indirgeme kuvveti tayini (FRAP metodu)}

Total indirgeme kuvveti tayini Oyaizu yöntemine göre yapılmıştır [23]. Stok çözeltilerden 25,50 ve $100 \mu \mathrm{g} / \mathrm{ml}$ olacak şekilde alınarak deney tüplerine aktarılmış ve ardından hacim saf suyla $1 \mathrm{ml}$ 'ye tamamlanmıştır. Daha sonra her bir tüpe $2,5 \mathrm{ml} \mathrm{0,2 \textrm {M }}$ tampon çözelti $(\mathrm{pH}: 6,6)$ ve $2,5 \mathrm{ml} \% 1$ 'lik potasyumferrisiyanür $\left[\mathrm{K}_{3} \mathrm{Fe}(\mathrm{CN})_{6}\right]$ ilave edilerek karışım $50{ }^{\circ} \mathrm{C}$ 'de $20 \mathrm{dk}$ inkübasyona bırakılmıştır. $\mathrm{Bu}$ işlemlerden sonra 
reaksiyon karışımına 2,5 $\mathrm{ml} \% 10$ 'luk triklorasetik asit (TCA) ilave edilmiștir. Santrifüj işleminden sonra çözeltinin üst fazından $2,5 \mathrm{ml}$ alınarak üzerine $2,5 \mathrm{ml}$ destile su ve 0,5 $\mathrm{ml} \mathrm{FeCl}_{3}$ ilave edildikten sonra absorbanslar 700 nm'de köre karşı okunmuştur. Kontrol için numune yerine saf su eklenmiş, kör olarak da sadece saf su kullanılmıştır.

\subsubsection{CUPRAC metoduna göre indirgeme kuvveti tayini}

Numunelerin, kuprik iyonu $\left(\mathrm{Cu}^{2+)}\right.$ indirgeme kapasiteleri Apak ve arkadaşları tarafından önerilen kuprak metoduna göre yapılmıştır [24]. Deney tüplerine $0,25 \mathrm{ml} \mathrm{CuCl} 2$ çözeltisi ilave edildikten sonra üzerine $0,25 \mathrm{ml} 7,5 \times 10^{-3} \mathrm{M}^{\prime}$ lık etanolik neokuprin çözeltisi ve $1 \mathrm{~mL}$ asetat tamponu aktarılmıştır. Ardından farklı konsantrasyonlarda (25$50-75 \mu \mathrm{g} / \mathrm{ml}$ ) etanol ekstraktları ve standartlar ilave edilmiştir. Yarım saatlik bir inkübasyondan sonra $450 \mathrm{~nm}$ 'de artan absorbansları kaydedilmiştir. Reaksiyon karışımının artan absorbansı artan kuprik iyon $\left(\mathrm{Cu}^{2+}\right)$ indirgeme kapasitesini göstermektedir.

\subsubsection{ABTS radikali giderme aktivitesi tayini}

$\mathrm{Wu}$ ve arkadaşlarının metoduna göre [25] ABTS radikallerinin giderilme aktivitelerinin belirlendiği bu çalışmada öncelikle $2,45 \mathrm{mM} \mathrm{K}_{2} \mathrm{~S}_{2} \mathrm{O}_{8}$ ve $7 \mathrm{mM}$ ABTS çözeltileri eşit oranda karıştırılarak oda sıcaklığında yaklaşık 15 saat inkübe edilmiştir. Kontrol absorbansını elde etmek için, hazırlanan bu ABTS radikal çözeltisinin 734 nm'deki absorbansı, 1,660 00,02 değerine ulaşana kadar etil alkolle seyreltilmiştir. Hazırlanan radikal çözeltisinden deney tüplerine $4 \mathrm{ml}$ konulmuştur. Bu tüplerin üzerine $50 \mu \mathrm{l}$ ve $100 \mu \mathrm{l}$ konsantrasyonlara sahip etanol ekstraktları ve standartlar eklenerek oda sıcaklığında inkübe edilmiştir (2 saat). Bu surenin sonunda ekstraktların absorbansı 734 nm'de kaydedilmiştir.

\subsubsection{1,1-Difenil 2-pikril hidrazil (DPPH) radikali giderme aktivitesi tayini}

Serbest radikal giderme amaçlı DPPH'’’n 1 mM'lık çözeltisinin kullanıldığ bu çalışma Blois metodununa [26] göre yapılmıştır. Deney tüplerine sırasıyla 25, 50 ve $100 \mu \mathrm{g} / \mu \mathrm{l}$ konsantrasyonlarında standartlar ve etanol ekstraktları aktarılmış ve toplam hacimleri 3 ml olacak şekilde etanol ile tamamlanmıştır. Daha sonra her bir tüpe DPPH• çözeltisinden $1 \mathrm{ml}$ ilave edilerek 30 dakika oda sıcaklığında inkübe edildikten sonra etanolden oluşan köre karşı 517 nm'de absorbansları kaydedilmiştir. Kontrol olarak, 3 $\mathrm{ml}$ etanol ve $1 \mathrm{ml}$ DPPH çözeltisi kullanılmıştır.

\subsection{Antimikrobiyal aktivite}

T. kotschyi ve T. tomentellum etanol ekstraktlarının aktivite tayini oyuk agar yöntemine göre yapılmıştır [27]. Bu çalışmada test organizması olarak $3 \mathrm{Gr}$ (+) (Bacillus subtilis ATCC 6633, Staphylococcus aureus ATCC 25923 ve Bacillus megaterium DSM 32), 4 Gr (-) (Enterobacter aerogenes ATCC 13048, Eshericha coli ATCC 11229, Pseudomonas aeroginosa ATCC 9027 ve Klebsiella pneumonia ATCC 13883) patojen bakterileri ve 3 fungusun (Yarrowia lipolytica, Candida albicans ATCC 10231 ve Saccharomyces cereviciae) dahil olduğu 10 farklı mikroorganizma kullanılmıştır. Test mikroorganizmaları Muş Alparslan Üniversitesi Merkezi Laboratuvarı'ndan temin edilmiştir.

Test bakteriler Nutrient Broth besiyerine, mayalar ise Sabourand \%2 Glukoz Broth'a aşılanmış ve mayalar $27{ }^{\circ} \mathrm{C}$ 'de, bakteriler ise $35{ }^{\circ} \mathrm{C}$ 'de inkübasyona bırakılarak üretilmiştir. Sıvı ortamda gelişen her mikroorganizma kültüründen, tekrar yukarıdaki sıvı ortamları içeren tüplere $\% 1$ oranında bakteri kültürü aşılanarak 18 saat inkübe 
edilmiştir. Nutrient Broth ve Sabourand \%2 Glukoz Broth besiyerleri $15 \mathrm{ml}$ olacak şekilde $9 \mathrm{~cm}$ 'lik petri kaplarına dökülmüş ve katılaştıktan sonra $4{ }^{\circ} \mathrm{C}$ 'de 1 saat bekletilmiştir. Hazırlanmış besi ortamına mikroorganizma kültürü drigalski spatülü yardımıyla yayılarak aşılanarak $10 \mathrm{~mm}$ çapında oyuklar açılmıştır. Ekstraktlardan $0,1 \mathrm{gr}$ tartılarak üzerine $1 \mathrm{ml}$ DMSO ilave edilmiştir. Hazırlanmış olan çözeltiden oyuklara 75, 100 ve $150 \mu \mathrm{l}$ ilave edilmiş ve bu kültürler 1 saat süre ile $4{ }^{\circ} \mathrm{C}$ 'de bekletilmiştir. Maya kültürleri ile aşılanmış olan besiyerler $27^{\circ} \mathrm{C}$ 'de, bakteri kültürleri ile aşılanmış olan besiyerler ise $37^{\circ} \mathrm{C}$ 'de $18-24$ saat inkübasyona bırakılmıştır. Test bakteri ve mayaların $\left(10^{6} \mathrm{CFUs} / \mathrm{ml}\right)$ bulanıklığı Mc Farland 0,5 standartına göre ayarlanmıştır [28]. Bu çalışmada Oxoid'ten temin edilen $6 \mathrm{~mm}$ çapında 5 adet antibiyotik disk (Eritromisin (E15), Ampisillin/sulbaktam (SAM-20), Rifampisin (RD-5), Amikasin (AK-30) ve Fluconazol (FCA-25) standart olarak kullanılmıştır. Bitki ekstraktları ve antibiyotiklerin farklı konsantrasyonları 10 farklı mikroorganizma üzerinde test edilmiş ve oluşan inhibisyon zonlarının çapları mm olarak ölçülmüştür.

\subsection{Bitki ekstraktlarının DNA üzerindeki etkileri}

pBR322 plazmid DNA kullanılarak ekstraktların DNA üzerindeki etkisi agaroz jel elektroforez yöntemi ile belirlenmiştir [29]. Bu amaçla $200 \mathrm{mg}$ ekstrakt $1 \mathrm{ml}$ DMSO'da çözülerek stok ekstraktlar hazırlanmıştır. Bu stok ekstraktlar seyreltilerek 25, 50 ve 100 $\mathrm{mg} / \mathrm{ml}$ konsantrasyonlarına sahip ekstraktlar kullanılmıştır. Her ekstraktın DNA üzerindeki etkisi agaroz jel elektroforezi yardımıyla belirlenmiştir. Jel örnekleri Tablo 2 'de verilen prosedüre göre hazırlanmıştır.

Tablo 2. Elektroforez Örneklerinin Bileșenleri ve Miktarları

\begin{tabular}{|c|c|c|c|c|c|c|}
\hline $\begin{array}{l}\text { Tüp } \\
\text { No }\end{array}$ & $\begin{array}{c}\text { DNA } \\
(\mu \mathrm{l})\end{array}$ & $\begin{array}{c}\mathrm{H}_{2} \mathbf{O}_{2} \\
(\mu \mathrm{l})\end{array}$ & $\begin{array}{c}\text { DMSO } \\
(\mu \mathrm{l})\end{array}$ & $\begin{array}{l}\text { Ekstraktlar }(10 \mu \mathrm{L}) \text { ve } \\
\text { konsantrasyonları }\end{array}$ & Saf Su $(\mu \mathrm{l})$ & $\begin{array}{c}\text { Toplam } \\
\text { Hacim }(\mu \mathrm{l})\end{array}$ \\
\hline 1 & 10 & - & - & - & 15 & 25 \\
\hline 2 & 10 & 5 & - & - & 10 & 25 \\
\hline 3 & 10 & 5 & 10 & - & - & 25 \\
\hline 4 & 10 & - & 10 & - & 5 & 25 \\
\hline 5 & 10 & 5 & - & Etanol ekstraktı $(100 \mathrm{mg} / \mathrm{ml})$ & - & 25 \\
\hline 6 & 10 & 5 & - & Etanol ekstrakt1 $(50 \mathrm{mg} / \mathrm{ml})$ & - & 25 \\
\hline 7 & 10 & 5 & - & Etanol ekstraktı $(25 \mathrm{mg} / \mathrm{ml})$ & - & 25 \\
\hline 8 & 10 & - & - & Etanol ekstraktı $(100 \mathrm{mg} / \mathrm{ml})$ & 5 & 25 \\
\hline 9 & 10 & - & - & Etanol ekstrakt1 $(50 \mathrm{mg} / \mathrm{ml})$ & 5 & 25 \\
\hline 10 & 10 & - & - & Etanol ekstraktı $(25 \mathrm{mg} / \mathrm{ml})$ & 5 & 25 \\
\hline
\end{tabular}

PCR tüpleri $37^{\circ} \mathrm{C}$ ' de 4 farklı zaman aralığında (3, 6, 12 ve 24 saat) karanlık ortamda inkübe edilmiştir. İnkübasyondan sonra DNA ekstrakt karışımının $5 \mu \mathrm{l}$ ' si yükleme tamponu ile karıştırılıp \%1' lik agaroz jele yüklenerek TBE tamponu içerisinde $40 \mathrm{~V}$ ' ta, serbest akımda, 2 saat süre ile elektroforez yapılmıştır. Elektroforezden sonra jeller etidyum bromid ile boyanarak CemiDoc XRS BIORAD görüntüleme sisteminde jel fotoğrafları görüntülenmiştir [30].

\section{Bulgular}

\subsection{Fenolik birleşiklerin HPLC ile analiz miktarları}

T. kotschyi ve T. tomentellum'dan elde edilen etanol ekstraktlarının fenolik madde içeriklerini belirlemek için 14 farklı fenolik standart kullanılarak miktar analizi HPLC cihazı ile yapılmış ve elde edilen sonuçlar Tablo 3 'de verilmiştir. 
Tablo 3. T. kotschyi (Boiss.) Grierson ve T. tomentellum (Boiss) Grierson ekstraktlarındaki fenolik bileşik miktarları $(\mu \mathrm{g} / \mathrm{ml})$

\begin{tabular}{ccc}
\hline Fenolikler & T. kotschyi & T. tomentellum \\
\hline Askorbik asit & $30.017,0$ & $43.514,4$ \\
Gallik asit & - & - \\
Mirisetin & $2.834,3$ & $5.169,3$ \\
Absisik Asit & $4.379,4$ & $56.844,8$ \\
Kuersetin & $5.687,2$ & $159.731,5$ \\
Apigenin & $126.573,8$ & $154.698,5$ \\
Kaemferol & $5.470,6$ & $3.608,5$ \\
Kurkumin & $77.477,8$ & $4.176,2$ \\
Katekol & $29.779,4$ & $11.758,3$ \\
Vanilin & $2.550,8$ & $1.082,2$ \\
Kafeik asit & $12.438,6$ & $1.504,8$ \\
Sinamik asit & $3.565,6$ & $2.771,2$ \\
Rozmarinik asit & $3.875,8$ & $3.143,0$ \\
Salisilik asit & - & $3.724,6$ \\
\hline
\end{tabular}

-: Sonuç Yok

Ekstraktların fenolik madde miktarlarına bakıldığında $T$. kotschyi ekstraktında en fazla miktarda apigenin $(126.573,8 \mu \mathrm{g} / \mathrm{ml})$, en az miktarda vanillin $(2,550,8 \mu \mathrm{g} / \mathrm{ml})$ varlığ tespit edilmiştir. T. tomentellum ekstraktında ise en az miktarda vanillin (1.082,2 $\mu \mathrm{g} / \mathrm{ml})$, en fazla miktarda ise kuersetin $(159.731,5 \mu \mathrm{g} / \mathrm{ml})$ olduğu belirlenmiştir. Gallik asit her iki ekstraktta tespit edilemezken, salisilik asit ise T. kotschyi ekstraktında tespit edilememiştir. Bitki ekstraktlarındaki fenolik madde miktarlarının birbirlerinden çok farklı olduğu belirlenmiştir (Şekil 1 ve Şekil 2).
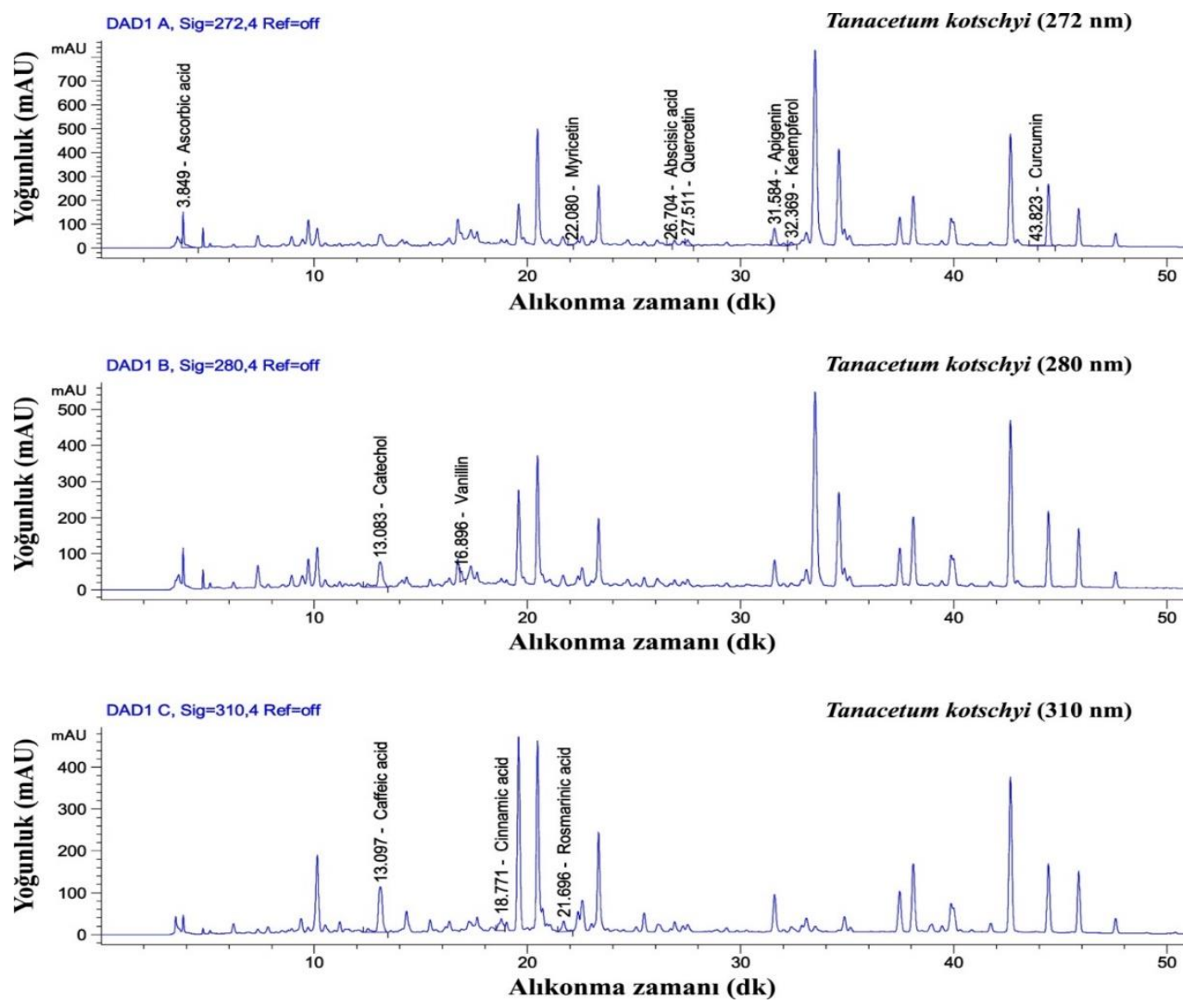

Şekil 1. Tanacetum kotschyi ekstrakt içeriğini gösteren HPLC kromatogramı 

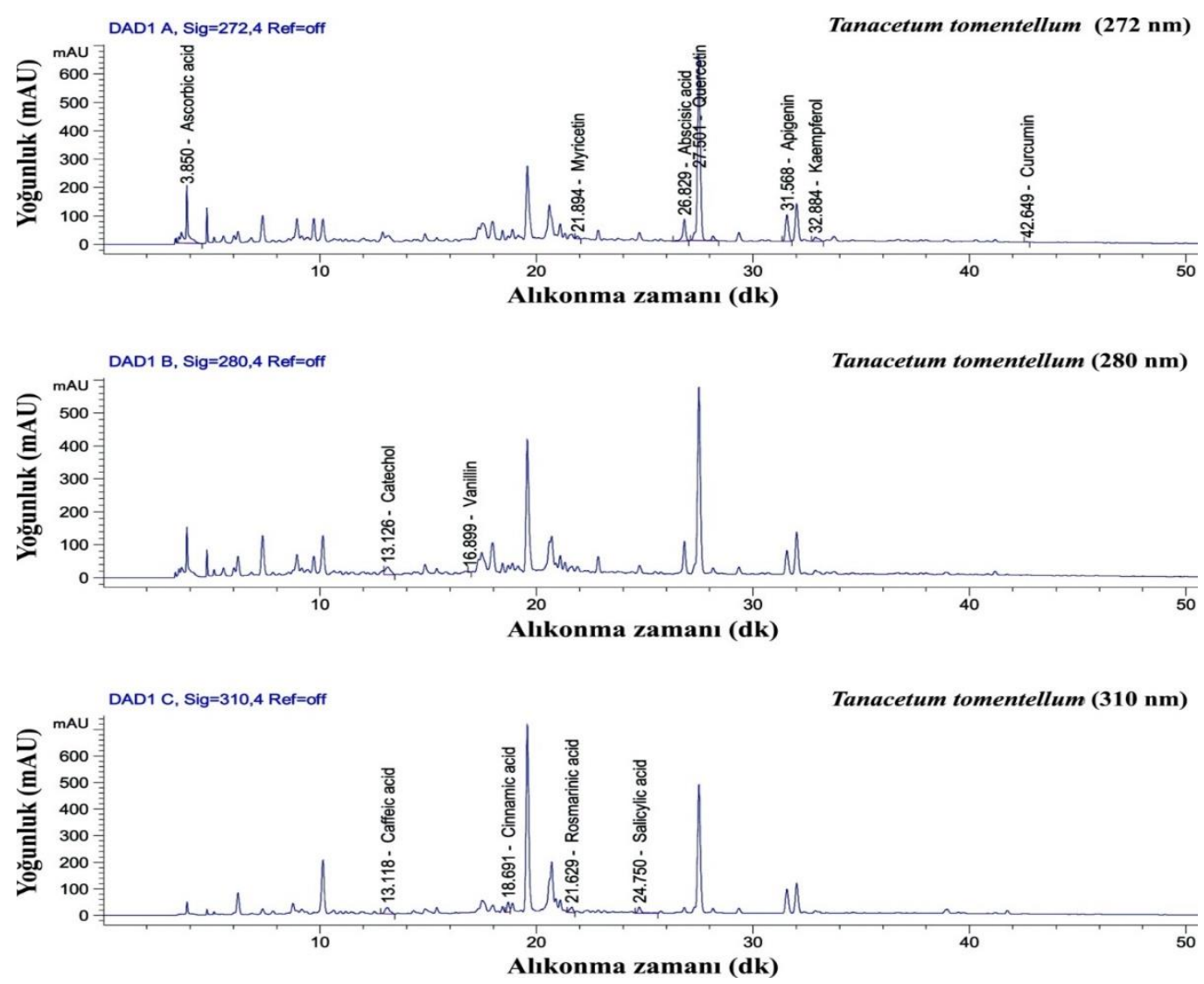

Şekil 2. Tanacetum tomentellum ekstrakt içeriğini gösteren HPLC kromatogramı

\subsection{Biyolojik aktivite sonuçları}

\subsubsection{Antioksidan özellikler}

\subsubsection{Total antioksidan aktivite}

T. kotschyi ve T. tomentellum etanol ekstraktları DMSO'da çözülerek total antioksidan aktiviteleri "Ferrik Tiyosiyanat Metoduna" göre belirlenmiştir. Bu metot linoleik asit emülsiyonunda oksidasyon sonucu oluşan peroksidin, spektrofotometrik olarak 500 nm'de ölçülmesi esasına dayanır. T. kotschyi ve T. tomentellum total antioksidan aktivite tayini için sırasıyla 25, 50 ve $100 \mu \mathrm{L}$ kullanılmıştır (Şekil 3a). Şekilde de görüldüğü gibi bitkilerin total antioksidan aktivitesi, numune konsantrasyonu ile genellikle doğru orantılı olarak artmaktadır. Bitki ekstraktlarının ve kullanılan standart antioksidanların linoleik asit emülsiyonunu inhibe etme yüzdeleri, kontrol değerinin maksimuma ulaştığı inkübasyon anı olan yirminci saat baz alınarak hesaplanmıştır. Hesaplamalar Denklem1'e göre yapılmıştır.

$$
\text { Lipid peroksidasyonu inhibisyonu }(\%)=100-\left(\frac{\mathrm{Ae}}{\mathrm{Ak}} \times 100\right)
$$

Burada; Ae: kontrol değerinin maksimum inkübasyon anındaki ekstraktların verdiği absorbans değeri, $A_{k}$ ise kontrolün absorbans değerini ifade eder.

$100 \mu \mathrm{L}$ 'lik $T$. kotschyi ve T. tomentellum linoleik asit emülsiyonunun oluşturduğu peroksidasyonu sirasiyla \%68,93 ve \%73,62 oranında inhibe ederken aynı miktarda BHA, BHT ve $\alpha$-tokoferol sirasiyla \% 72,34, \% 72,76 ve \% 57,87 oranında inhibe ettiği gözlenmiştir. 


\subsubsection{Indirgeme kuvveti tayini (FRAP)}

Ekstraktların indirgeme kapasiteleri konsantrasyona bağlı olarak artmaktadır. İndirgeme kuvveti her bir ekstrakt için $25 \mu \mathrm{l}, 50 \mu \mathrm{l}$ ve $100 \mu \mathrm{l}$ 'lik miktarlarının bulunduğu test çözeltilerinin $700 \mathrm{~nm}$ 'de absorbanslarının ölçülmesiyle belirlenmiştir.

BHA, BHT ve $\alpha$-tokoferol ile karşılaştırıldığında $T$. kotschyi ve $T$. tomentellum için indirgeme kuvveti kapasiteleri şu şekilde siralanmaktadır (Şekil 3b): BHA $>T$. tomentellum $>$ T. kotschyi $>$ BHT $>\alpha$-tokoferol.

\subsubsection{Indirgeme kuvveti tayini (CUPRAC)}

T. kotschyi ve T. tomentellum ekstraktlarının kuprik iyonlarını $\left(\mathrm{Cu}^{2+}\right)$ indirgeme kapasitesinin ekstraktların konsantrasyonu ile doğru orantılı olarak arttığı görülmüştür. Her iki bitkinin 25,50 ve $75 \mu$ l miktarlarının kuprik iyonlarını $\left(\mathrm{Cu}^{2+}\right)$ indirgeme kapasitesi 450 nm'deki absorbansları ölçülerek belirlenmiştir (Şekil 3c).

\subsubsection{ABTS $^{\cdot+}$ radikal giderme aktivitesi}

T. kotschyi ve $T$. tomentellum ile standartların 50 ve $100 \mu l^{\prime}$ deki ABTS $^{\circ+}$ radikal giderme aktivitesi sonuçlarına bakıldığında hepsinin birbirine yakın ve çok iyi aktivite gösterdiği söylenebilir. ABTS radikali yok etme yüzdeleri şu şekilde sıralanmaktadır (Şekil 3d): BHT $(\% 96,16) \geq \alpha$-tocopherol $(\% 96,15) \geq$ BHA $(\% 96,04) \geq T$. tomentellum $(\% 95,98) \geq T$. kotschyi $(\% 95,80)$.

\subsubsection{DPPH' serbest radikal giderme aktivitesi}

DPPH radikali uzun ömürlü bir azot radikalidir. Antioksidan maddelerin radikal giderme aktivitelerini belirlemek için en sık kullanılan metotlardan biridir. Bu metotta antioksidan maddeler DPPH radikallerini, sarı renkli difenilpikrilhidrazine indirger. Ekstraktların DPPH radikallerini konsantrasyona bağlı olarak doğru orantılı şekilde giderdiği görülmüştür (Şekil 3e). Ekstraktların $100 \mu$ 'sinin DPPH radikali giderme aktiviteleri standartlar ile kıyaslandığında standartlara çok yakın değerlere sahip olduğu gözlenmiştir. $100 \mu$ l'lik $T$. kotschyi ve T. tomentellum ile standartlar sırasıyla şu şekilde DPPH radikali giderme aktivitesi sergilemişlerdir; BHA $(\% 91,74) \geq \alpha$-tocopherol $(\% 91,23) \geq$ BHT $(\% 90,50) \geq T$. tomentellum $(\% 90,17)>T$. kotschyi $(\% 90,0)$. 

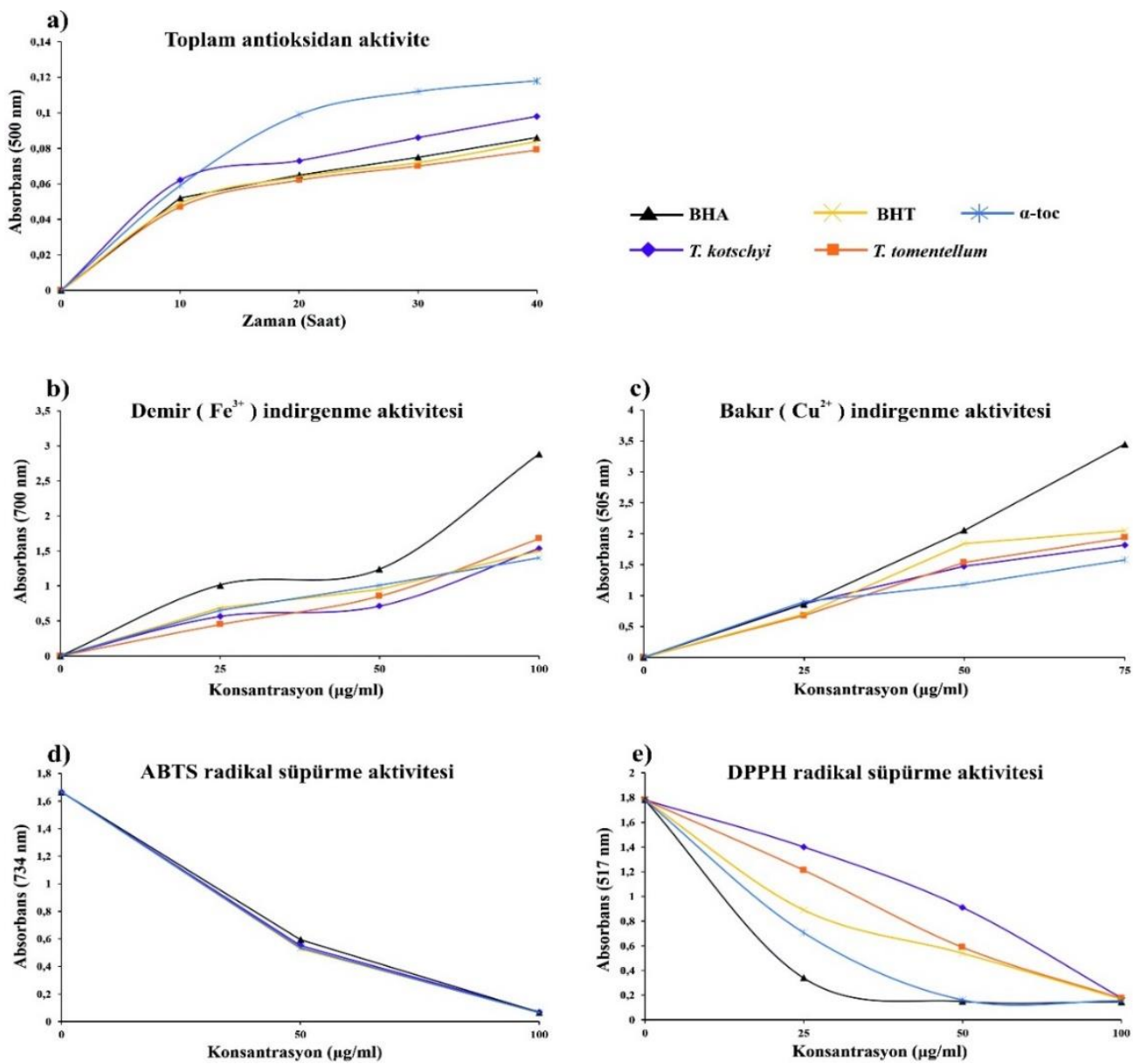

Şekil 3. $T$. kotschyi ve T. tomentellum etanol ekstraktları ve standart antioksidanların in vitro antioksidan aktivite sonuçları. Standart antioksidanlar: BHA: Bütillenmiş hidroksianisol, BHT: Bütillenmiş hidroksitoluen ve $\alpha$-toc: $\alpha$-tokoferol. a) Total antioksidan aktivitelerin zamana bağlı değişimi, b) FRAP yöntemiyle demir indirgenmesinin konsantrasyona bağlı değişimi c) CUPRAC yöntemiyle bakır indirgenmesinin konsantrasyona bağlı değişimi d) ABTS radikal giderme aktivitesinin konsantrasyona bağlı değişimi e) DPPH radikal giderme aktivitesinin konsantrasyona bağlı değişimi

\subsection{Antimikrobiyal aktivite çalışmaları}

T. kotschyi ve T. tomentellum etanol ekstraktlarının mikrooganizmalar üzerindeki antimikrobiyal özelliklerini aydınlatmak için $B$. subtilis, S. aureus, B. megaterium, E. aerogenes, E. coli, $P$. aeroginosa, $K$. pneumonia, $Y$. lipolytica, $C$. albicans ve $S$. cereviciae test mikroorganizmaları üzerindeki antibakteriyal ve antifungal aktiviteleri mm olarak belirlenmiştir (Tablo 4).

Tablo 4. T. kotschyi (Boiss.) Grierson ve T. tomentellum (Boiss.) Grierson ekstraktlarının test mikroorganizmaları üzerindeki antimikrobiyal etkisi (İnhibisyon zonları $\mathrm{mm}$ olarak gösterilmektedir.)

\begin{tabular}{cccccccc}
\hline \multirow{2}{*}{ Mikroorganizmalar } & \multicolumn{3}{c}{ T. kotschyi } & \multicolumn{3}{c}{ T. tomentellum } \\
& & $\mathbf{7 5} \boldsymbol{\mu}$ & $\mathbf{1 0 0} \boldsymbol{\mu l}$ & $\mathbf{1 5 0} \boldsymbol{\mu l}$ & $\mathbf{7 5} \boldsymbol{\mu l}$ & $\mathbf{1 0 0} \boldsymbol{\mu l}$ & $\mathbf{1 5 0} \boldsymbol{\mu l}$ \\
\hline \multirow{2}{*}{ Gram } & B. subtilis & $14 \pm 1,00$ & $15 \pm 0,00$ & $17 \pm 1,52$ & $15 \pm 0,00$ & $17 \pm 1,00$ & $20 \pm 0,57$ \\
pozitif & S. aureus & - & - & $18 \pm 1,00$ & $21 \pm 1,15$ & $22 \pm 0,57$ & $27 \pm 1,73$ \\
& B. megaterium & $12 \pm 0,00$ & $13 \pm 1,00$ & $14 \pm 0,00$ & $13 \pm 1,00$ & $16 \pm 0,00$ & $17 \pm 1,00$ \\
\hline \multirow{3}{*}{ Gram } & E. aerogenes & $12 \pm 1,00$ & $12 \pm 0,00$ & $14 \pm 0,57$ & $15 \pm 0,00$ & $17 \pm 0,00$ & $19 \pm 1,15$ \\
negatif & E. coli & $15 \pm 1,52$ & $16 \pm 1,15$ & $18 \pm 1,52$ & $17 \pm 1,73$ & $19 \pm 1,15$ & $21 \pm 0,57$ \\
& P. aeroginosa & $12 \pm 0,00$ & $15 \pm 1,00$ & $16 \pm 0,00$ & $16 \pm 0,57$ & $18 \pm 1,00$ & $20 \pm 1,52$ \\
& K. pneumonia & $18 \pm 1,15$ & $20 \pm 1,73$ & $27 \pm 1,15$ & $14 \pm 1,00$ & $16 \pm 0,00$ & $20 \pm 1,73$ \\
\hline \multirow{2}{*}{ Fungus } & Y. lipolytica & $13 \pm 0,00$ & $18 \pm 1,52$ & $20 \pm 1,00$ & $15 \pm 0,00$ & $18 \pm 0,57$ & $22 \pm 1,00$ \\
& C. albicans & $18 \pm 1,00$ & $20 \pm 0,57$ & $28 \pm 1,73$ & $15 \pm 1,52$ & $19 \pm 1,15$ & $22 \pm 0,57$ \\
& S. cereviciae & - & - & - & $13 \pm 0,00$ & $16 \pm 1,00$ & $18 \pm 0,00$ \\
\hline
\end{tabular}

-: inhibisyon zonu oluşmad1. 
T. kotschyi ve T. tomentellum ekstraktları $12 \mathrm{~mm}$ ile $28 \mathrm{~mm}$ arasında antimikrobiyal aktivite göstermiştir. T. kotschyi ekstraktının en fazla antimikrobiyal aktiviteyi $C$. albicans üzerinde $(28 \pm 1,73 \mathrm{~mm})$, en az antimikrobiyal aktiviteyi ise E. aerogenes, $B$. megaterium ve $P$. aeroginosa üzerinde gösterdiği belirlenmiştir. $T$. tomentellum ekstraktı en az aktiviteyi $B$. megaterium ve $S$. cereviciae üzerinde gösterirken, en fazla aktiviteyi ise $S$. aureus üzerinde $(27 \pm 1,73 \mathrm{~mm})$ gösterdiği tespit edilmiştir. Ayrıca $T$. kotschyi ekstraktının $S$. cereviciae üzerinde herhangi bir etkiye sahip olmadığı tespit edilmiştir. Ekstraktların konsantrasyonlarındaki artışa bağlı olarak antimikrobiyal etkinin de arttığı gözlemlenmiştir. Ayrıca çözücü olarak kullanılan DMSO'nun test mikroorganizmaları üzerinde herhangi bir antimikrobiyal aktivite göstermediği belirlenmiştir.

Antibiyotiklerin test mikroorganizmalar üzerindeki etkileri belirlenmiştir. Sonuçlar Tablo 5'te gösterilmektedir. T. kotschyi ve T. tomentellum ekstraktları kontrol amaçlı olarak kullanılan antibiyotikler ile karşılaştırıldığında genel itibariyle eşit ölçüde inhibisyon zonu oluşturarak, benzer antimikrobiyal aktivite gösterdikleri tespit edilmiştir.

Tablo 5. Antibiyotik disklerinin test mikroorganizmalarına karşı antimikrobiyal etkisi (İnhibisyon zonları mm olarak gösterilmektedir.)

\begin{tabular}{|c|c|c|c|c|c|c|}
\hline \multirow{2}{*}{\multicolumn{2}{|c|}{ Mikroorganizmalar }} & \multicolumn{5}{|c|}{ Antibiyotikler } \\
\hline & & \multirow{2}{*}{$\begin{array}{c}\text { Eritromisin } \\
20 \pm 0,00\end{array}$} & \multirow{2}{*}{$\begin{array}{c}\begin{array}{c}\text { Ampisillin/ } \\
\text { sulbactam }\end{array} \\
14 \pm 1,15\end{array}$} & \multirow{2}{*}{$\begin{array}{c}\text { Amikasin } \\
11 \pm 1,00\end{array}$} & \multirow{2}{*}{$\begin{array}{c}\text { Rifampisin } \\
21 \pm 0,00\end{array}$} & \multirow{2}{*}{$\begin{array}{c}\text { Flukonazol } \\
-\end{array}$} \\
\hline$\approx$. & B. subtilis & & & & & \\
\hline 氖 & S. aureus & $21 \pm 1,00$ & $10 \pm 0,00$ & $9 \pm 0,00$ & $18 \pm 1,15$ & - \\
\hline $0 \AA$ & B. megaterium & $25 \pm 0,00$ & -2 & $10 \pm 1,00$ & $16 \pm 0,00$ & - \\
\hline \multirow{4}{*}{ 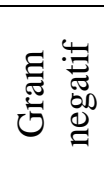 } & E. aerogenes & $27 \pm 1,00$ & $10 \pm 1,00$ & $9 \pm 0,00$ & $16 \pm 1,00$ & - \\
\hline & E. coli & $19 \pm 1,52$ & $13 \pm 0,00$ & $13 \pm 0,00$ & $18 \pm 0,00$ & - \\
\hline & P. aeroginosa & $19 \pm 0,00$ & - & $14 \pm 1,15$ & $8 \pm 0,00$ & - \\
\hline & K. pneumonia & $19 \pm 1,73$ & $16 \pm 0,57$ & $10 \pm 0,00$ & $19 \pm 1,73$ & - \\
\hline \multirow{3}{*}{$\underbrace{\infty}_{\Xi}$} & Y. lipolytica & - & - & - & - & $21 \pm 0,00$ \\
\hline & C. albicans & - & - & - & - & $23 \pm 1,52$ \\
\hline & S. cereviciae & - & - & - & - & - \\
\hline
\end{tabular}

-: inhibisyon zonu oluşmadı.

\subsection{DNA koruyucu aktivite}

DNA, canlılarda farklı formlarda bulunabilir ve bu formlar canlının genetik karakterine göre şekillenirler. Herhangi bir molekül bu DNA ile etkileștiğinde bu formların bozulmasına veya birbirlerine dönüşmesine neden olabilir. DNA'nın çift zincirli süper sarmal yapısı form I olarak bilinir. Form I yapısını teşkil eden iplikçiklerden birinin kırılması sonrasında agaroz jelde daha yavaş hareket eden ve form I'e göre daha gevşek yapıya sahip form II meydana gelir. Buna ek olarak diğer zincirin kırılması sonrasında DNA lineer hale gelir ve bu yapı form III olarak bilinir [31]. İlgili DNA molekülü agaroz jel üzerinde yürütülerek bu formlar görüntülenebilir.

Estraktların plazmid DNA ile etkileşimi sonucunda oluşan değişiklikler, Form I, Form II ve Form III dönüşümü gözlemlenerek belirlenmiştir (Şekil 4). 


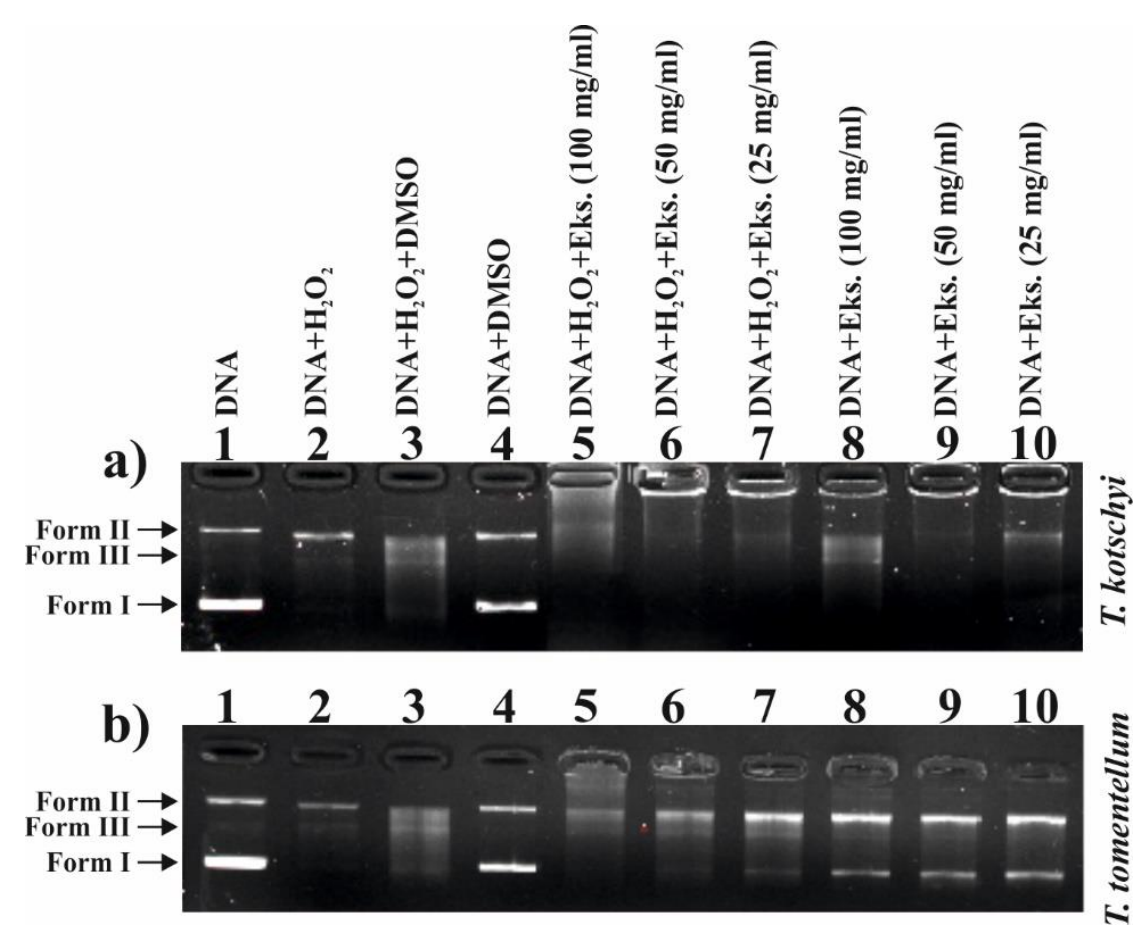

Şekil 4. Ekstraktların pBR322 plazmid DNA's1 üzerindeki koruyucu etkilerini gösteren agaroz jel görüntüsü. a) T.kotschyi ekstraktının etkisi b) T.tomentellum ekstraktının etkisi

Jel görüntüsüne göre $\mathrm{H}_{2} \mathrm{O}_{2}$ 'nin tek başına Form I'i parçaladı̆̆ 1 , DMSO ile birlikte DNA'yı tamamen yok ettiği gözlenmiştir. DMSO'nun tek başına DNA'yı kısmen etkilediği belirlenmiştir. $T$. kotschyi ekstraktının, $\mathrm{H}_{2} \mathrm{O}_{2}+$ DMSO'un birlikte verdiği süpürücü etkiyi azaltmamakla birlikte tek başına uygulandığında DNA'yı parçalayarak kararsız hale gelmesine neden olduğu gözlenmiştir (Şekil 4a). Bunun aksine $T$. tomentellum'dan elde edilen ekstraktın artan konsantrasyonuna bağlı olarak, $\mathrm{H}_{2} \mathrm{O}_{2}+$ DMSO'un süpürücü etkisini ortadan kaldırarak DNA'yı kararlı hale getirdiği gözlenmiştir (Şekil 4b).

\section{Sonuç ve Yorum}

Yapılan literatür araştırmasında T. kotschyi ve T. tomentellum ile ilgili fenolik içerik ve biyolojik aktivite araştırmalarına ait çalışmaların çok kısıtlı olduğu görülmüştür. Bundan dolayı bu çalışmada $T$. kotschyi ve T. tomentellum etanol ekstraktlarının HPLC ile fenolik madde miktarları ve in vitro biyolojik aktiviteleri araştırılmıştır.

Tanacetum'un farklı bir türünde yapılan bir çalışmada ekstraktın HPLC-MS analizi sonucunda az oranda gentisik asit, luteolin, kafeik asit ve klorojenik asit tespit edilmesine karşın en fazla miktarda kuersetin $(27,61 \pm 0,39 \mu \mathrm{g} / \mathrm{g})$ ve apigenin $(9,71 \pm$ $0,18 \mu \mathrm{g} / \mathrm{g}$ ) varlığı tespit edilmiştir [32]. LC-MS cihazı ile yapılan başka bir çalışmada ise üç farklı Tanacetum türünün fenolik içeriklerine bakıldığında T. vulgare ekstraktında kuersetin belirlenebilmesine karşın her üç türde de kaemferol ve apigenin varlığı tespit edilememiştir [33]. T. vulgare üzerine olan benzer bir çalışmanın iki farklı ekstraktında kuersetin belirlenirken, T. vulgare (Sibiu) ekstraktında ise apigenin varlığ edilebilmiştir. Ayrıca her iki ekstraktada kafeik asit ve kaemferolün önemsenmeyecek derecede az olduğu bildirilmiştir [34].

Bu çalışmada 14 farklı fenolik madde içeriğine bakıldı ve gallik asit her iki ekstraktta, salisilik asit ise T. tomentellum ekstraktında tespit edilememiştir. Sonuçların daha önceki çalışmaların sonuçlarından farklı olmasının nedeni kullanılan bitki türleri ve çözücülerin farklı olmasından kaynaklandığı düşünülmektedir. 
Tanacetum cinsine ait çeşitli in vitro antioksidan çalışmalar mevcuttur. Yapılan bir çalışmada $T$. abrotanifolium türünün farklı ekstraktlarının biyolojik aktiviteleri incelenmiş ve metanol-diklorometan ekstraktının total antioksidan kapasitesinin en yüksek olduğu bildirilmiştir [35]. Başka bir çalışmada T. gracile türüne ait farklı ekstraktlar hazırlanmış ve biyolojik aktiviteleri incelenmiştir. Çalışmanın sonuçlarına göre bitki ekstraktlarının indirgeme kapasitesinin standartlara çok yakın olduğu rapor edilmiştir [36]. Benzer bir çalışmada T.macrophyllum etanol ekstraktının çok güçlü indirgeme kapasitesine sahip olduğu bildirilmiştir [37]. Aynı çalışmada $T$. macrophyllum uçucu yağlarının ABTS radikallerini süpürme aktivitelerinin araştırıldığı bir çalışmada bitkinin troloks antioksidanına göre çok daha yüksek aktivite sergilediği rapor edilmiştir [37]. Ayrıca T. parthenium uçucu yağlarının DPPH radikallerini süpürme aktivitelerinin çok yüksek olduğu ve doğal antioksidan olarak kullanılabiceği rapor edilmiştir [38]. DPPH radikal giderme aktivitesi ile ilgili T. kotschyi (Boiss.) metanol ve etilasetat ekstraktları ile yapılan bir çalışmada, metanol ekstraktının BHT ve $\alpha$-tokoferol standartlarının aktivitelerine yakın etki gösterdiği bildirilmiştir. CUPRAC metodu kullanılarak yapılan bu bitkiye ait herhangi bir antioksidan çalışmaya rastlanılmamıştır.

T. kotschyi ve T. tomentellum etanol ekstraktları ile yapılan bu çalışmanın sonuçlarında ekstraktların BHA, BHT ve $\alpha$-tokoferol standartlarına yakın veya daha yüksek antioksidan aktivite sergilemişlerdir. Fenolik içerikleri ile kıyaslandığında antioksidan özelliklerinin fenolik içerikleriyle paralel olduğu ve yukarıdaki çalışmaları desteklediği belirlenmiştir.

İnsan sağlığı üzerindeki olumlu etkileri ve zararlı mikroorganizmalar üzerindeki öldürücü özellikleri bakımından bitkiler, son yüzyılda bir çok araştırmacı için ilgi odağ olmuştur [39]. Önceki çalışmalarda T. corymbosum ekstraktının $S$. aureus üzerinde en iyi antibakteriyal aktiviteye sahip olduğu, ancak $E$. coli ve $P$. aeruginosa üzerinde herhangi bir etkisinin olmadığı görülmüştür. Aynı zamanda ekstraktların C. albicans ve C. parapsilosis üzerinde önemli seviyede antifungal etkiye sahip olduğu rapor edilmiştir [33]. Başka bir çalışmada T. kotschyi bitkisinin gövdesinden elde edilen ekstraktın $C$. parapsilosis' e karşı yüksek antimikrobiyal aktivite gösterdiği belirlenmiştir [40]. Farklı bir tür üzerinde yapılan çalışmada $T$. vulgare ekstraktlarının $C$. albicans, $E$. coli ve $P$. aeruginosa üzerinde herhangi bir antimikrobiyal aktivite göstermediği $B$. subtilis ve $S$. aureus üzerinde kısmen antibakteriyal aktivite gösterdiği tespit edilmiştir [34]. $T$. zahlbruckneri (Náb.) Grierson hekzan ekstraktının, Gr (-) bakteriler (E. coli ve $P$. vulgaris) ve mantar (A. niger) üzerinde herhangi bir aktivite göstermediği ancak $\mathrm{Gr}(+)$ bakteriler üzerinde orta derecede etkili olduğu bildirilmiştir [41].

Bu çalışmada ekstraktların sadece $S$. cereviciae üzerinde etki göstermediği ancak diğer tüm test mikroorganizmalar üzerinde antimikrobiyal aktiviteye sahip olduğu gözlenmiştir. Ayrıca esktraktların eritromisin ve rifampisine benzer oranda, ampisillin/sulbactam ve amikasinden daha iyi antibakteriyel aktiviteye sahip olduğu görülmüştür. Aynı zamanda ekstraktların flukonazol'e benzer oranda antifungal aktivite gösterdiği tespit edilmiştir.

Antioksidanların ortamda bulunan $\mathrm{H}_{2} \mathrm{O}_{2}$ gibi çeşitli molekülleri elimine ederek DNA üzerinde koruyucu etkilerinin bulunduğunu belirten çeşitli çalışmalar yapılmıştır. Ekstraktın biyolojik aktivite çalışmalarının son aşamasında DNA koruyucu aktiviteleri araştırılmıştır. Yapılan bir çalışmada Asteraceae familyasına ait Cyanthillium cinereum su ekstraktının DNA'yı $\mathrm{H}_{2} \mathrm{O}_{2}$ 'in oluşturduğu hasara karşı koruduğu tespit edilmiştir [42]. Türkiye'de sivas çevresinden toplanmış olan I. oculus-christi toprak üstü kısımlarından elde edilen su ekstraktının $\mathrm{H}_{2} \mathrm{O}_{2}$ ve UV 1şınları uygulanarak hasara uğratılan pBR322 DNA plazmiti üzerinde, koruyucu etki gösterdiği gözlenmiştir [43]. Bu çalışmada $T$. kotschyi etanol ekstraktının DNA üzerinde bir etki göstermediği, $T$. 
tomentellum ekstraktının ise $\mathrm{H}_{2} \mathrm{O}_{2}$ 'nin süpürücü etkisini ortadan kaldırarak DNA'y1 kararlı hale getirdiği tespit edilmiştir.

Sonuç olarak daha önce yapılan çalışmalarda bu bitki türüne ait sınırlı sayıda çalışma olduğundan, bu çalışmanın literatüre önemli bir katkı sağlayacağı, ileri düzeyde yapılacak farmakolojik çalışmalar için bir kaynak olabileceği, fenolik içerikleri ve biyolojik aktivite sonuçları göz önünde bulundurulduğunda bu bitkilerin doğal antioksidanlar olarak kullanılabileceği düşünülmektedir.

\section{Kaynakça}

[1] A. L. Branen, "Toxicology and biochemistry of butylated hydroxyanisole and butylated hydroxytoluene", J Am Oil Chem Soc., vol. 52, p.59-63, 1975.

[2] J. G. Sebranek, V. J. H. Sewalt, K. L. Robbins and T. A. Houser, "Comparison of a Natural Rosemary Extract and BHA/BHT for RelativeAntioxidant Efectiveness in Pork Sausage”, Meat Sci., vol. 69: pp. 289-296, 2005.

[3] A. S. Alkofahi, A. Abdelaziz, I. Mahmoud, M. Abuirjie, A. Hunaiti and A. El-Oqla "Cytotoxicity, mutagenicity and antimicrobial activity of forty jordanian medicinal plants", Int $J$ Crude Drug Res., vol. 28(2), pp. 139-144, 1990.

[4] E.O. Wilson, "Biodiversity”, National Academic Press, Washington, 1986.

[5] K. Bremer, "Asteraceae: Cladistics and Classification" Timber Press, Portl. Oregon, 1994.

[6] M. Mucciarelli, M. Maffei and C.W. Wright, "Introduction To The Genus". Taylo R \& Francis Publishing, Newyork, Pp.1-51, 2002.

[7] P. H. Davis (Ed.), "Flora Of The Turkey And The East Aegean Islands", Edinburgh University Press, Vol. 1- 9, Edinburgh, 1985.

[8] P. H. Davis, R. R. Mill and K. Tan, "Flora Of Turkey And The East Aegean Islands", Edinburgh University Press, Vol.10, Edinburgh 1988.

[9] N. Özhatay and Ş. Kültür, "Check- List Of Additional Taxa To The Supplement Flora Of Turkey III”, Tr. J. Bot., vol. 30, pp. 281-316, 2006.

[10] M. Doğan, "Türkiye Jurinea Cass. (Asteraceae) Cinsinin Revizyonu”, Doktora Tezi, Selçuk Üniv., Fen Bilimleri Ens., Konya, 2007.

[11] CH. Oberprieler, R. Vogt and LE. Watson, (Tribe Anthemideae Cass. In: Kadereit JW, Jeffrey C, editors), "The Families and Genera of Vascular Plants", Springer, Vol. 8, 2007.

[12] M. Korkmaz, A. Kandemir, V. İlhan and N. Doğan Yıldırım, "Tanacetum erzincanense (Asteraceae), a new species from Erzincan, Turkey”, Turk J Bot, vol. 38, 2014.

[13] A. J. C. Grierson, (Tanacetum L. Davis, P. H., (Ed.)), "Flora Of The Turkey And The East Aegean Islands", Edinburgh University Press, Vol. 5, Edinburgh, 1975.

[14] N. Çelik, “Türkiye'nin Tanacetum Türleri Üzerinde Sistematik ve Kimyasal Bir araştırma”, Doktora tezi, Ankara Üniv., Ankara, 1977.

[15] A. Güner, S. Aslan, T. Ekim, M. Vural ve M.T. Babac, "Türkiye Damarlı Bitkiler Listesi”, Nezahat Gökyiğit Botanik Bahçesi ve Flora Araştırmaları Derneği Yayını, İstanbul, s. 118-120, 2012.

[16] P. Gürbüz, D. Eroğlu, Ş.D. Doğan, G. Şeker Karatoprak, M.Yavuz Paksoy ve M. Koşar “Tanacetum Zahlbruckner (Náb.) Grıerson' nun Sekonder Metabolitleri ve Antioksidan Etkileri” Sağlık Bilimleri Dergisi (Journal of Health Sciences); 26 (1), 2017.

[17] T. Sibanba and A.I. Okoh, "The challenges of overcoming antibiotic resistance plant exracts as potential sources of antimicrobial and resistance modifiying agents", Africa J. Biotech., V: 6(25), pp. 2886-2896, 2007.

[18] H.M. Shang, H.Z. Zhou, J.Y. Yang, R. Li, H. Song, and H.X. Wu "In vitro and in vivo antioxidant activities of inulin." PloS one, 13(2), e0192273. 2018.

[19] Y. Alan, A. Savc1, B. Çakmak and H. Kurt, "Determination of The Antimicrobial and Antioxidant Activities of Satureja hortensis Ingredients" Yüzüncü Yll Üniversitesi Fen Bilimleri Enstitüsü Dergisi/ Journal of The Institute of Natural and Applied Sciences 21 (2) 167-177, 2016.

[20] D. Ahmed, M. Mehboob Khan and R. Saeed "Comparative Analysis of Phenolics, Flavonoids, and Antioxidant and Antibacterial Potential of Methanolic, Hexanic and Aqueous Extracts from Adiantum caudatum Leaves" Antioxidants, 4, 394-409, 2015.

[21] S. Tapan, "Quantitative HPLC Analysis of Phenolic Acids, Flavonoids and Ascorbic Acid in Four Different Solvent Extracts of Two Wild Edible Leaves, Sonchus Arvensis and Oenanthe Linearis of North-Eastern Region in India”, J. appl. pharm. sci., vol. 6 (2), 157-166, 2016.

[22] H. Mitsuda, K. Yasumoto and K. Wami, "Antioxidative action of indole compounds during the autoxidation of linoleic acid”, Eiyoto Shokuryo, vol. 19, pp. 210-214, 1966.

[23] M. Oyaizu, "Studies on product of browning reaction prepared from glucose amine", Jpn J Nutr., vol. 44, pp. 307-315, 1986. 
[24] R. Apak, K. Güçlü, M. Özyürek, S.E. Karademir and E. Erça "The cupric ion reducing antioxidant capacity and polyphenolic content of some herbal teas." Int J Food Sci Nutr, 57, 292-304, 2006.

[25] L. Wu, L. Chang, S. Chen, N. Fan and J.A. Ho, "Antioxidant activity and melanogenesis inhibitory effect of the acetonic extract of Osmanthus fragrans: A potential natural and functional food flavor additive", LWT- Food Sci Technol Res., vol. 42, pp. 1513-1519, 2009.

[26] M.S. Blois, "Antioxidant determinations by the use of a stable free radical”, Nature, vol. 26, pp. 1199-1200, 1958.

[27] O. Sağdıç, A.G. Karahan, M. Özcan and G. Özkan, "Effect of Some Species Extracts on Bacterial İnhibition”, Food Sci Technol Int.,vol. 9(5), pp. 353-356, 2003.

[28] J. Hindler, "Tests to assess bactericidal activity", In Clinical Microbiology Procedures Handbook. Ed, Eisenberg HD. Washington, DC: American Society for Microbiology, pp. 5.16.14-5.16.24, 1992.

[29] T. L. Siddall, D. G. Ouse, Z. L. Benko, G. M. Garvin, J. L. Jackson, J. M. McQuiston, M. J. Ricks, T. D. Thibault, J. A. Turner, J. C. VanHeertum and M.R. Weimer, "Synthesis and Herbicidal Activity of Phenyl-substituted Benzoylpyrazoles", J Pest Sci., vol. 58, pp. 1175-1186, 2002.

[30] M. Londershausen, "Approaches to new parasiticides”, J Pestic Sci., vol. 48 (4), pp. 269-292, 1996.

[31] H. Zhang, J.M. Barcelo, B. Lee, G. Kohlhagen, D.B. Zimonjic, N.C. Popescu and Y. Pommier, "Human Mitochondrial Topoisomerase I", Proc Natl Acad Sci U S A, vol. 98(19), pp. 10608-10613, 2001.

[32] D. Hanganu, D. Benedec, L. Vlase, I. Popıca, C. Bele, O. Raita, A.Gheldıu, C. V. Mihalı and V. Țărmure, "Polyphenolic Content and Antioxidant Activity of Chrysanthemum Parthenium Extract", Farmacia, vol. 64, 4,pp. 49 8, 2016.

[33] B. Ivănescu , C. Tuchıluș , A. Corciovă , C. Lungu , C. T. Miha1 , A.Gheldıu and L. Vlase, "Antioxidant, Antimicrobial and Cytotoxic Activity of Tanacetum Vulgare, Tanacetum Corymbosum and Tanacetum Macrophyllum Extracts, Farmacia, Vol. 66, pp. 2, 2018.

[34] M. Mureşan, D. Benedec, L. Vlase, R. Oprean, A. Toıu and I. Onıga, "Screening Of Polyphenolic Compounds, Antioxidant And Antimicrobial Properties Of Tanacetum Vulgare From Transylvania". Studia Ubb Chemia, Lx, vol. 1, PP. 127-138, 2015.

[35] İH. Geçibesler, "In Vitro Biological Activity Studies on Tanacetum Abrotanifolium (L.) Druce (Asteraceae)". Anadolu Univ. J. of Sci. and Technology A-Appl. Sci. and Eng. Vol. 18 (2), 2017.

[36] M. Bhatnagar, AS. Avasthi and AS. Ghosal, "In Vitro Antibacterial and Antioxidant Activity of High Altitude Medicinal Plant Tanacetum Gracile". Int J Pharm Bio Sci Apr ; vol. 8(2): (B), pp. 914-921, 2017.

[37] A. Venditti, C. Frezza, F. Sciubba, M. Serafini, A. Bianco, K. Cianfaglione, G. Lupidi, L. Quassinti, M. Bramucci and F. Maggi, "Volatile components, polar constituents and biological activity of tansy daisy (Tanacetum macrophyllum (Waldst. et Kit.) Schultz Bip.)", Ind Crops Prod., vol. 118, pp. 225235, 2018.

[38] F. Rezaei, R. Jamei and R Heidari, "Evaluation of the Phytochemical and Antioxidant Potential of Aerial Parts of Iranian Tanacetum parthenium". Res Pharm Sci, vol. 23, 136-142, 2017.

[39] M. Digrak, M.H. Alma, A. İlçim and S. Sen, "Antibacterial and Antifungal Effects of Various Commercial Plant Extracts”, Pharm Biol., vol. 37(3), pp. 216-22, 1999.

[40] T. Öztekin, “Tanacetum kotschyi (Boiss.) Bitkisi Üzerinde Fitokimyasal Araştırmalar ve Biyoaktivite Çalışmaları. Yüksek Lisans Tezi, Yıldız Teknik Üniv., Fen Bilimleri Ens., İstanbul, 94-98.

[41] F. P. Çağlar, “Tanacetum Zahlbruckneri(Náb.) Grierson Bitkisi Üzerinde Yağ Asitleri Tayini Ve Biyoaktivite Çalışmaları”, Yüksek Lisans Tezi, Yıldız Teknik Üniv. Fen Bilimleri Ens., İstanbul, S. 102, 2011.

[42] G. Guha, V. Rajkumar, R. A. Kumar and L. Mathew, "Therapeutic Potential of Polar and Non-polar Extracts of Cyanthillium cinereum In vitro", eCAM, PP. 1 of 11, 2009.

[43] Ş. Berk, B. Bektaş and S. Arslan, "Screening of the antioxidant, antimicrobial and DNA damage protection potentials of the aqueous extract of Inula oculus-christi", Afr. J. Pharm. Pharmacol., Vol. 5(14), pp. 1695-1702, 2011. 